\title{
Increasing the Potential of Work, Leading New Leaders
}

\author{
MSC. Adriana Zotaj \\ Prof. Asoc.Dr. Bernard Zotaj \\ Military Armed Forces of Albania, Ministry of Defense, Tirana \\ Email: adrianazotaj@yahoo.com
}

\section{Doi:10.5901/ajis.2015.v4n2s2p200}

\begin{abstract}
Any business organization faces constant environmental changes. In order to follow various trends and developments, companies are required to develop an efficient information system. By carefully analyzing this information they can identify opportunities or threats, moreover they can classify if an opportunity is an development opportunity for the organization, or minimize the impact of the threat. Nowadays, changes must include new and difficult objectives as well as painful applications. The intent is to change something, abandone the old and apply something new; Acceptance of change. The Japanese have a term called "Kaizen" which means continuous improvement. |This is never the end to ask for something to be done better.
\end{abstract}

Keywords: Business, organization, developments, analyzing, opportunities

"The intended purpose of the leader is to change a particular situation"(Boriçi, 2009). During the change, which serves to create a good group, leaders must guide their people to follow acceptable changes through identification and implementation of:

- Vision - Leader's basic element. The leader knows where you are going, and why, but he also knows why we can not go further.

- Passion- is another basic element of leadership. The leader loves what he performs. Without hope, no one can survive, or move towards no matter how little progress one can make. People who exhibit passion give hope and inspiration to others. This element is often confused with enthusiasm.

- Human values- should be reflected in any leadership and from there spread to the citizens.

- Leaders must motivate the group to accomplish goals.

- "Knowledge of human nature is a very important element of the leadership activity.

- People need to see someone stronger than themselves, but also more human.

Gen. Colin Powell in his book "My American Journey," states:

"A good vision is a mental modeling of the future. It gives purpose and ways to be followed to move towards the final goal. Good vision promotes enthusiasm of the people and it should be ambitious.

Vision promotes the commitment and energy of the people, it gives meaning to their lives, creates standards of excellence and serves as a bridge between the present and the future"(Powell,1999).

"A good leader must motivate people and must convey vision at every level of management. Formulating a vision is only the first step. Those who have a clear vision of where to lead people should come in the Strategic leadership. This vision must be real and convince those who are governed, it is accessible; It must be credible and inspire you; It should be attractive for people to feel themselves part of the projected future, and should provide for the future, to show people that no where and what they are now, but where to go and what to be. Good leader, "must collect around himself around people who are able to organize and lead others to achieve the objectives derived from the vision. It is an indispensable requirement that leaders choose the right people, who would become their strongest side in achieving the vision. " A good leader must motivate people and convey the vision at every level of management.

The vision must be communicated to all people by using all means and ways. The good leader not only should believe and to publish the vision but also support it. He must do so through strategic planning. Meanwhile planning shows where to go, strategic planning should determine how to get there, given the concrete situation.(Powell, 1999)

In the book "Strategic Management, theories, concepts, applications,"is stated: The vision of an organization is an enlarged picture of what the leader wants the organization to become in the future.

Vision is composed of three elements: mission, goals and philosophy of the organization. Creating a vision is no 
easy task, while it is an essential first step that defines our future. A vision is not a road map. It is a description of the destination where we intend to go. Without it, the roadmap does not matter. Once the vision is drafted, we can use different routes to get there. Vision serves to build a dream, but we can not say that the vision is just a dream; it should be based and rely on opportunities that may arise. Vision is based and consists of three important components: It is built on the mission or purpose, includes the goals and aspirations, as well as philosophy (values and basic beliefs). He becomes the basis for developing strategies and plans the vision is achieved by. When talking about vision we do not deal with a deliberate plan, designed to respond to the changes. An effective vision is conceptual in nature: it is an intuitive ability to see new chances in the opportunities that rise ahead of you. Mostly these are opportunities that others do not see or do not understand their importance and potential. So the vision is not a tool for predicting the future, but it is to create a positive future by undertaking actions in the future. Vision is the "dream" that people are connected with, who dedicate their time and effort to achieve.(Kume,2004)

In the above-mentioned book "Strategic Management, theories, concepts, applications" some of the lessons drawn from the leadership of Alexander the Great, are listed and among other things, it is stated:

- "Create a vision that implies collective imagination" states the great Alexander, ...... Effective leaders must be clear about the current situation and where they want to redirect people. Alexander knew where he was going and how to get there. Unfortunately he did not know how and when to stop.

Vision is one of the most important aspects of creating a successful group. Groups crumble when they do not clearly see their vision, what they are doing, why you are doing and where they want to achieve.

"It is necessary to understand well that leaders are decision makers who establish objectives to be realized. Time to realize the goals for each leader and leadership is limited. Organizing exact time should be one of the primary values of leadership. Leaders are not only to lead, but they are also educators. They should give good example and reflect kindly to citizens of the state they represent. Human values should be reflected in any leadership and from there spread to the citizens". (Boriçi 2009)

Wisdom obtained from your personal life story gives a good start. So says ... Mayor Rudolph Giuliani the world major, the man of 2001, selected by the newspaper "Time" in his book "Leadership". Writing with a familiar style, a bluntly speech of a New Yorker leavened by his passion for ideas, Giuliani reveales how the leadership skills he has followed, can be applied successfully by anyone who intends to do something.

He had more faith to us, from what we had in ourselves, because he proved to be brave when required, tough when needed, as well as soft but not slow acting, because they did not sleep, did not give up and return back from pain around him. Once he took over a city destroyed by the crime, Giuliani realized that every aspect of his career, since he had been an excellent lawyer when he had to fight against organized crime while he was federal prosecutor, was helping him to form his concept of leadership preparing him for other challenges to overcome. Giuliani victories thus strengthened his conviction for the basic qualities needed to be a successful leader.

There are many ways to lead. Some people such as Franklin Roosevelt inspire with their touching words. Others like Joe Di Maxhio, lead by their personal example. Winston Churchill and Douglas Mak Arthur were both extremely brave and brilliant rhetoricians. Ronald Reagan led by relying on his own strength and fortitude of his character. People followed him because they trusted him. Finally you will learn what techniques and ways work best. People who you hope to lead will tell themselves. A good part of your ability to push and make them what they really need to do, depends on what they can catch, while watching and listening to you. They need to see someone stronger than themselves, but also more humane.(Giuliani,2002)

- Leaders must motivate the group to accomplish goals.

Leaders in charge of various groups or organizations know that they can not spend money on any problem, they need to engage people more flexible, encourage action to make a quick and acceptable change as long as it is necessary.

- A next trial of the leader will be creating opportunities, chances, tasks and confidence for the group and the people within it.

Motivational Management determines the positive effects within the organization, contributes to the development and growth of the company's performance. It significantly increases the productivity of physical and intellectual work of the staff.

"Furthermore, motivation has to do with factors that activate human behavior, factors that govern human behavior towards a particular goal or objective, the creation of conditions that this behavior or attitude preserved and supported. So motivation is not abstract, but concrete. During motivation many of its associated components and elements interact and coordinate opposing each other or giving an attitude resultant behavior or action. These elements which can be combined 
may be: physiological, psychological, and social but others are still unexplained. Taken together they generate internal energy body, which make it possible to perform a different job or activity, realize certain attitudes or mode behavior".(Military and the leader, 2009)

"But we must emphasize that the process of motivation is an orientation and oriented process. This means that starting initial actions can be controlled and commanded from within the organism (the individual himself) and the motives and external stimuli. (environment society) Thus, in certain situations we guide our behavior towards meeting the needs ahead, and after they are met, the strength of motivation falls and it needs some time to regenerate energy and to begin efforts to meet any other need. As mentioned above, results that the motivation can be analyzed better in this causal order: Needs> Encourage or motivate > oriented behavior > Achieving the goals. This process is a cyclic process that never ends. The fulfillment of a need, we will surely give birth to a new one which will initiate a new motive, and so it is endless.

Human behavior is extremely complex and therefore it is not difficult to understand why each of motivation theories can not explain all the things that people do. The future will bring even more interesting results. Since the end of 1800 , William James highlighted the importance of motivation at work. He found out that employees do their work hours using $20-30 \%$ of their ability. On the other hand motivated employees worked with $80-90 \%$ of their capacities. He concluded that motivated employees can bring significant increase in labor productivity and reduction of problems such as delays, lack, removals complaints. Therefore good knowledge of motivation theories will help a lot any leader to achieve not only to direct collaborators (his subordinates) but also achieves the assigned objectives; not only to survive, but also succeed. "'" In this sense we will be able to answer a key question: What motivates people to work, do they fight more?

According to the Scientific Management theory, represented by Frederick W Taylor "when very productive people find out that they are rewarded almost equally with the less productive ones, then their productivity will decrease gradually. With the "Taylor" system employees are interested to work harder for a better reward and the amount of production is increased. This theory is based on the concept that "money is the main motivator", the financial rewards are directly related to productivity and the amount of work, so it makes employees work more. Nowadays this theory expands its effects in many productive and nonproductive activities. (in a more moderate form)

- Theory of Justice. -handled by J Stacey Adams was based on the idea that "people want to be treated fairly in relation to others"

- Masllov`s theory, also known as "humanist theory" where Abraham Masllovi (1908-1970) declared that "every theory on motivation should see the individual as a whole and should be based on a hierarchy of needs, which if met satisfactorily make someone realize its full potential.

- Theory of needs to be attached. - attachment theory needs. (for achievement, power and respect) - handled at first by David Mc Clelland is based on the logic that "people have desires to seek and establish connections with other people" while Masllovi regarded independent needs of people, this theory assumes that needs to be taught.

- Theory of Motivation-Hygiene (or Herzberg) - which mainly explains the motivation and job satisfaction. This theory distinguishes two main needs: needs to progress, qualified as factors that bring pleasure, and hygiene needs qualified as factors that bring temporary pleasure and displeasure. Conversely by having this knowledge leader should know how to behave with his associates and follow work practices to reduce as much as hygiene factors and establish motivating factors. In their work, leaders must manage to provide: commitment, achievement, reasonable growth and development which are called "keys to work enrichment "

- Theory of predicting motivation. - elaborated by Victor $\mathrm{H}$ Vroom is based on the idea that:-the employees trust as regards: connections among efforts, future performance and results determine their level of motivation.

Of all the theories of motivation valuable lessons are drawn for a leader. In other words as we have already mentioned above all various theories that deal with motivation conclude that "motivation is a behavior to achieve the goal" Theories although may look different are not in conflict with each other, they provide different perspectives but complementing each other, giving us a more complete picture of the process and the importance of motivation should be paid. No single theory on motivation provides all the answers, but connecting them into a principal scheme a clearer picture will be created regarding the necessity and the important role of each one. It is the primary duty of every leader to encourage and motivate people who cooperates with and are his dependents to achieve the required goals and mission. So every leader must perform better the so called "engine function" with the people who interact. It should motivate not one or several people, but the entire group that he leads. Historically motivation has been and will remain one of the keys to success.

Motivation should be understood as a psychological process of one or more persons working together with a 
common goal. For this purpose, the leader must understand and realize virtually the compliance of the goal. He must aim to encourage everyone in achieving the goal, encourage partners and subordinates in a certain attitude and behavior that the duty imposes him.(Military and the leader, 2009)

- "Knowledge of human nature is a very important element of leadership activity".

This allows managers to "better recognize his subordinates associates, their nature, their interests and motivations, desires and feelings, disappointment and concerns, family life, the past and hopes for the future"(Kouplend, 1993). In this way it will be easier to build lasting relationships with them in the view of the unit.

Better recognition of the nature of subordinates, their character, enables executives to rely confidently on them, having true partners in the implementation of each task. For this reason, he should create such a climate that subordinates be active members in all multilateral activities of the unit. So his success, the leader should support, inter alia, the mutual trust, honor, respect and security to subordinates.

"The leader should be in contact with subordinates, constantly and not only on labor, in order to create a wider recognition, even, if possible, to know and the personal opinion of each subordinat.(Bern, 1994). Thus the leader is able to assess the qualities and abilities of subordinates, to promote and to put them to work, so that any problem, no matter how complicated life, get solved within the required deadline.

\section{Recommendations}

The common denominator of any leader is the knowledge of the element "man", making a partner in the activity of the unit, giving him responsibilities by creating mutual trust.(Military leadership 2, 2011). To be an effective leader, people must have unquestionable faith in you in some way, they must be included in your vision.

In any group, institution or organization, the actions of a leader are the ones who decide the success or failure. This action gains the trust, loyalty and ensures the continued vitality of the group or organization. One way to build trust is to show a good sense of your character.

As a conclusion, I can say that: leaders and managers are radically reconsidering their philosophy, concepts and means.

\section{References}

Boriçi, Gj. (2009). Book "Power and Leadership" Dr. Gjon Boriçi. Publishing house "Ufo Press" September 2009ISBN978-99956-19-411.p, 126 .

Powell, C.(1999). Book "My American Journey", Colin Powell p. 9, Military Publishing House.Tirana, (1999). translated by Astrit Gjunkshi, original title "My American Yourney", published by Random House, New York, SHBA, 1995.

Powell, C.(1999). Book "My American Journey", Colin Powell, Military Publishing House.Tirana, 1999, translated by Astrit Gjunkshi, origjinal title "My American Yourney" p .10, published by Random House, New York, SHBA, 1995.

Kume, V.(2004).Book "Strategic Management, theory, concepts, applications", Author Prof. Dr. Vasilika Kume, Tirana 2004, Publishing house "Pegi" ISBN 99927-688-5-1, p. 95, 63, 64.

Boriçi, Gj. (2009). Book "Power and leadership" Dr Gjon Boriçi. Publishing house "Ufo Press" September 2009ISBN978-99956-19-411.p. 126.

Giuliani, R.( 2002), Rudy Giuliani Publisher "Leadership" Book: Hyperion; 1st edition (October 1, 2002) Hardcover: 407 pages, English preface, ISBN-10: 0786868414 ISBN-13: 978-0786868414

Military and the leader.(2009). Book "Military and the leader", Publishing Center and Military Translation, Tirana 2009, Publishing house "Kristalina", Ministry of Defence, General Staff, p. 114, 115, 116, 126,

Military and the leader.(2009).Book "Military and the leader", Publishing Center and Military Translation, Tirane 2009, Publishing House "Kristalina", Ministry of Defence, General Staff, p. 126,140,142, 133.

Kouplend, N.(1993). Book, Norman Kouplend, "Psycology and soldier ", SHBU, Tiranë 1993, page 152.

Bern, A. (1994). Alfred H. Bern, "Who wins battles", SHBU, Tirana 1994, page 23.

Military Leadership 2.(2011). "Military Leadership 2", MPH, Tirana 2011, page 28 